\title{
Parasites as biological tags for stock identification of blackspot seabream, Pagellus bogaraveo, in Portuguese northeast Atlantic waters
}

\author{
MARGARIDA HERMIDA ${ }^{1,2}$, CRISTINA CRUZ ${ }^{1,2}$ and AURÉLIA SARAIVA ${ }^{1,2}$ \\ ${ }^{1}$ Faculdade de Ciências, Universidade do Porto, Departamento de Biologia, Rua do Campo Alegre, Edifício FC4, 4169-007 \\ Porto, Portugal.E-mail: amsaraiv@ fc.up.pt \\ ${ }^{2}$ CIIMAR, Interdisciplinary Centre of Marine and Environmental Research, University of Porto, Rua dos Bragas, 289, \\ 4050-123 Porto, Portugal.
}

\begin{abstract}
SUMMARY: In this study the following parasites were selected as biological tags for the identification of blackspot seabream (Pagellus bogaraveo) stocks in the northeast Atlantic: Diphterostomum vividum (Digenea: Zoogonidae), Anisakis simplex s.l., A. physeteris, Anisakis sp. PB-2010 (Nematoda: Anisakidae), and Bolbosoma sp. (Acanthocephala: Polymorphidae). These parasite species point to the existence of three blackspot seabream stocks in the northeast Atlantic: one in the Azores region (ICES Area X), one in continental Portuguese shelf/slope waters (ICES Area IXa), and one in the waters around Madeira (sub-area 1.2 of FAO 34, central-eastern Atlantic).
\end{abstract}

Keywords: parasites, biological tags, populations, stocks, northeast Atlantic, blackspot seabream, Pagellus bogaraveo.

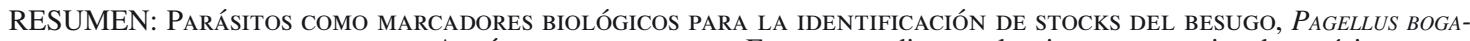
RAVEO, EN AGUAS PORTUGUESAS DE ATLÁNTICO NORDESTE. - En este estudio se seleccionaron especies de parásitos como marcadores biológicos para la identificación de las poblaciones de besugo (Pagellus bogaraveo) del Atlántico nordeste: Diphterostomum vividum (Digenea: Zoogonidae), Anisakis simplex s.l., A. physeteris, Anisakis sp. PB-2010 (Nematoda: Anisakidae), y Bolbosoma sp. (Acanthocephala: Polymorphidae). Estas especies de parásitos indican la existencia de tres poblaciones distintas de besugo en el Atlántico nordeste: una en la región de los Azores (ICES Zona X), otra en la plataforma/ talud continental portugués (ICES Zona IXa), y una tercera en las aguas adyacentes a la isla de Madeira (Subzona 1.2 de la FAO 34, Atlántico centro-este).

Palabras clave: parásitos, marcadores biológicos, poblaciones, stocks, Atlántico nordeste, besugo, Pagellus bogaraveo.

\section{INTRODUCTION}

The blackspot seabream, Pagellus bogaraveo (Brünnich, 1768), is a benthopelagic sparid fish that occurs in the northeast Atlantic and Mediterranean Sea, mostly on the continental shelf break and slope, on seamounts and around islands, at depths of up to $800 \mathrm{~m}$ (Spedicato et al. 2002, Menezes et al. 2006). It is a slow-growing and relatively long-lived species, with a protandric hermaphroditic reproductive system. All these features render it particularly vulnerable to fishing pressure, which indeed has already caused the collapse of the Cantabrian Sea stock (Lorance 2011). At present, the most important grounds for commercial fisheries of blackspot seabream are the waters around the Azores archipelago (ICES Area X).

Little is known about the population structure of this important sparid fish in the northeast Atlantic. Studies of mitochondrial DNA markers show that $P$. bogaraveo exhibits an exceptionally low genetic variability, consistent with the occurrence of a past bottleneck (Bargelloni et al. 2003, Stockley et al. 2005, Lemos et al. 2006), which has been estimated to have happened in the late Pleistocene, a period characterized by strong 
climate change (Patarnello et al. 2007). Stockley et al. (2005), however, point out that recent effects of fishing, especially the reduction in the number of females, could also have contributed to the low diversity in the mitochondrial genome.

A study using microsatellite markers found no significant genetic differentiation between Mediterranean and Atlantic blackspot seabream populations along the European continental shelf/slope, which might be due to the absence of strong barriers to gene flow (Piñera et al. 2007), whereas a morphological study detected some variation in morphometric features between populations, but no geographical gradient to this variation (Palma and Andrade 2004). Within the northeast Atlantic significant, albeit low, genetic variation has been detected in the mitochondrial D-loop region and microsatellite markers between populations from mainland Portuguese waters and the Azores (Stockley et al. 2005; Lemos et al. 2006).

Identifying stocks is of primary interest to fisheries management because population dynamics such as recruitment and the response to fishing pressure can operate independently on individual stocks (Waldman 1999). Though at first sight there appear to be less conspicuous barriers in the ocean than in other ecosystems, marine fish can exhibit a complex population structure (Abaunza et al. 2008). In some cases, such as when recent recolonization has occurred after an evolutionary bottleneck event, population structure may be effectively invisible to the most commonly used genetic markers; in such cases, using an additional non-genetic approach, such as biological tagging, can enhance resolution (Waldman 1999).

Parasitological approaches can be excellent indicators of stock separation (Pawson and Jennings 1996). Parasites can be used as biological tags since their geographic ranges are limited by the abiotic and ecological conditions that permit their development and completion of their life cycles. The principle of the method is that a fish can only become infected with a parasite when entering its endemic range (MacKenzie and Abaunza, 2005). In order to qualify as an appropriate biological tag, a parasite must be present with different infection levels in the fish host within the study area, must remain in the host for long periods of time (usually more than a year), and should not cause serious pathology or alter its host's behaviour (MacKenzie and Abaunza 1998, 2005).

Due to the almost complete lack of information on the parasite fauna of blackspot seabream in the northeast Atlantic Ocean, a comprehensive survey was carried out in the study area, in order to permit selection of appropriate parasite tags, as recommended by MacKenzie and Abaunza (2005). Here we select appropriate parasite tags for the study of $P$. bogaraveo populations, following the criteria outlined in Lester (1990), MacKenzie and Abaunza (1998, 2005), and further clarified by Lester and MacKenzie (2009). We then proceed to analyse that information with a view to identifying $P$. bogaraveo
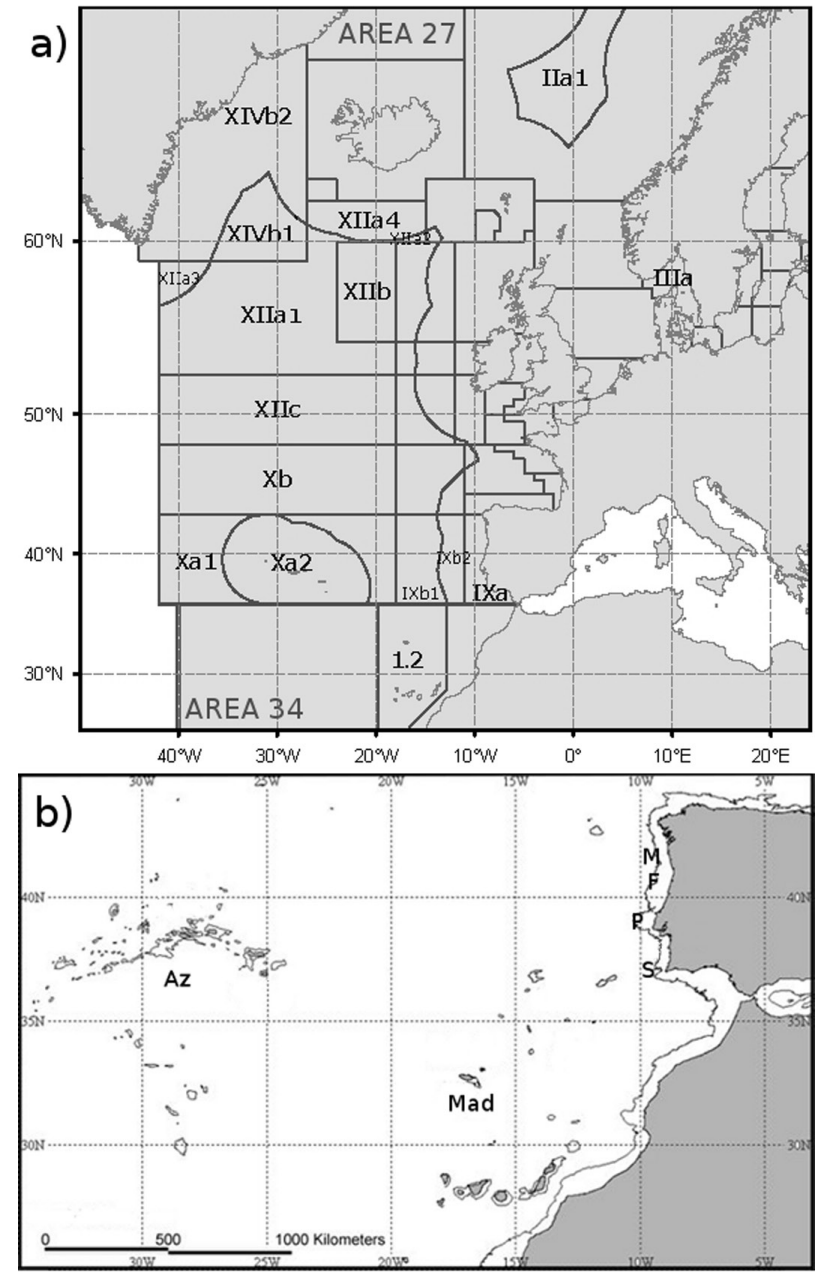

FIG. 1. - A, map of the north-east Atlantic with ICES divisions; B, sampling localities on the Portuguese mainland coast (M, Matosinhos; F, Figueira da Foz; P, Peniche; S, Sagres) and islands (Mad, Madeira; Az, Azores).

stocks in the study area. The main aim of this paper is to provide additional information that will complement genetic studies, in order to achieve a better understanding of the population structure of blackspot seabream in northeastern Atlantic waters.

\section{MATERIALS AND METHODS}

A comprehensive study on the metazoan parasite fauna of blackspot seabream in the north-east Atlantic was carried out from 2009 to 2011. A total of 348 fish were obtained from commercial catches, including the archipelagos of Madeira (56 specimens) and the Azores (86), and four localities on the Portuguese mainland coast: Matosinhos (42), Figueira da Foz (92), Peniche (42) and Sagres (30) (Fig. 1). Sampling was carried out during the spring/summer and autumn/winter periods, except at Sagres where only spring/summer samples were obtained.

Fish were dissected and observed for the presence of metazoan parasites according to routine parasitological techniques. All parasites detected were collected, 
TABle 1. - Prevalence of parasites of Pagellus bogaraveo from Portuguese waters and statistically significant differences between localities and/or regions detected by chi-square test (similar letters indicate no statistical differences). Ectoparasite results previously in Hermida et al. (2013); gastrointestinal parasites in Hermida et al. (in press).

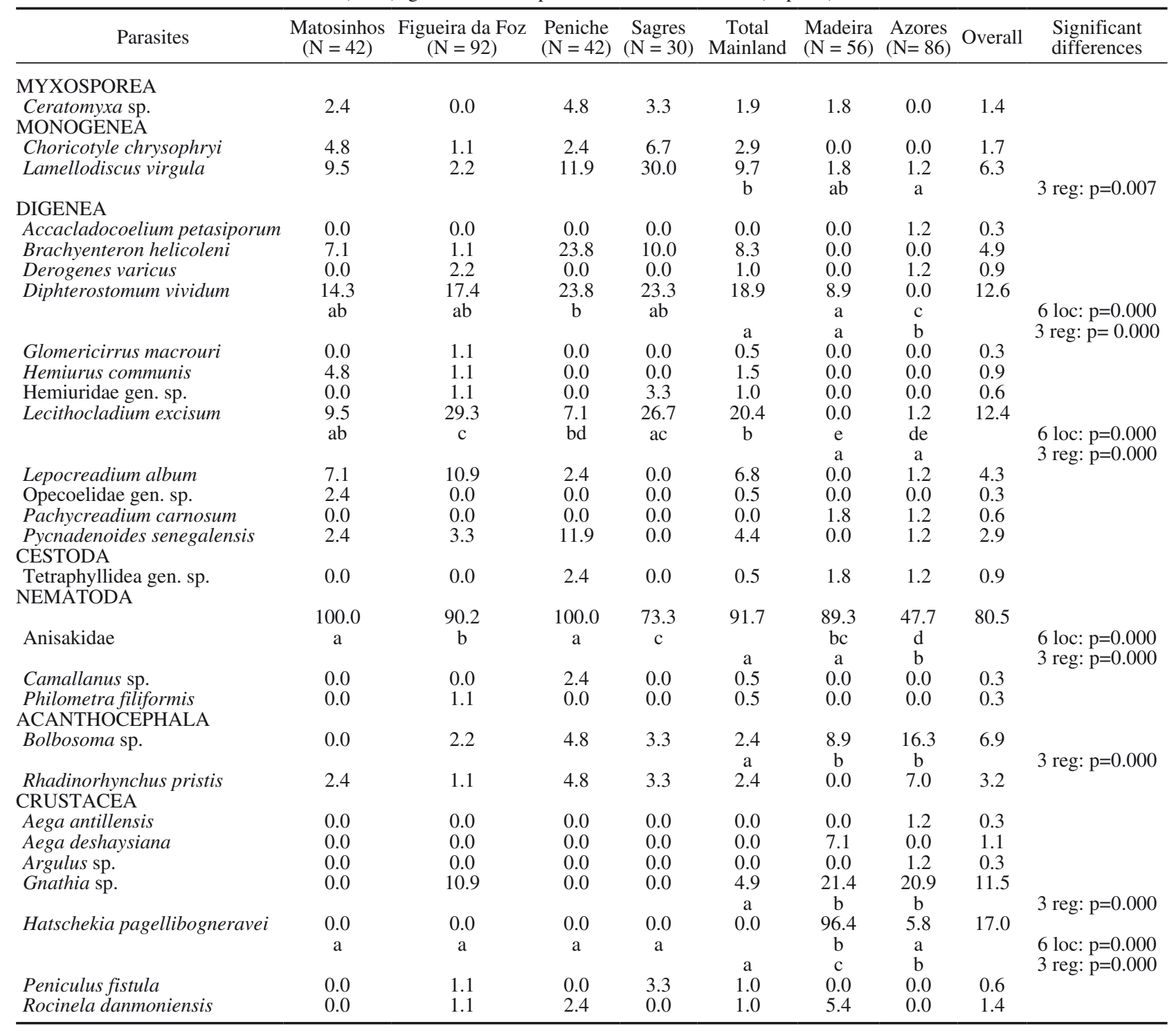

counted, preserved in 70\% (v/v) ethanol and processed according to taxonomic group. Parasites were observed in a Zeiss Axiophot optical microscope and measurements were taken using a digital camera and the Axiovision Zeiss Image Analysis System. All parasites except anisakid nematodes were morphologically identified to the lowest possible taxonomic rank following taxonomic guides and original descriptions in the literature. Anisakid nematodes are parasitic in fish as juveniles, and can only be identified to species level using molecular techniques. Due to the large number detected, a sub-sample of more than 30 specimens was randomly selected within the anisakids collected from each locality for identification using polymerase chain reaction-restriction fragment length polymorphism and/or sequencing of the ITS (Internal Transcribed Spacer) region (Hermida et al. 2012).
Prevalence of infection and mean abundance were determined according to Bush et al. (1997). Prevalence was the preferred parameter for comparisons among localities since it reflects encounter rates between parasites and hosts and is therefore more strongly determined by local factors (Poulin 2006). Statistical analyses were carried out using the IBM SPSS statistics software. Whenever possible, prevalence was compared among all localities and also between the three regions (Azores, Madeira, and the mainland) using a chi-square test, followed by multiple comparisons whenever significant differences were detected. Statistical significance was accepted when $p<0.05$. In the case of anisakid nematode species, because of the necessity of subsampling, relative abundance was used instead. Pairwise analyses of relative abundances of the molecularly identified anisakid species between locali- 
TABLE 2. - Abundance (mean \pm sd, range) of parasites of Pagellus bogaraveo from Portuguese waters.

\begin{tabular}{|c|c|c|c|c|c|c|c|c|}
\hline Parasites & $\begin{array}{c}\text { Matosinhos } \\
(\mathrm{N}=42)\end{array}$ & $\begin{array}{c}\text { Figueira da } \\
\text { Foz }(\mathrm{N}=92)\end{array}$ & $\begin{array}{l}\text { Peniche } \\
(\mathrm{N}=42)\end{array}$ & $\begin{array}{l}\text { Sagres } \\
(\mathrm{N}=30)\end{array}$ & $\begin{array}{c}\text { Total } \\
\text { Mainland }\end{array}$ & $\begin{array}{l}\text { Madeira } \\
(\mathrm{N}=56)\end{array}$ & $\begin{array}{l}\text { Azores } \\
(\mathrm{N}=86)\end{array}$ & Overall \\
\hline \multicolumn{9}{|l|}{ MONOGENEA } \\
\hline Choricotyle chrysophryi & $\begin{array}{c}0.05 \pm 0.22 \\
(0-1)\end{array}$ & $\begin{array}{c}0.01 \pm 0.10 \\
(0-1)\end{array}$ & $\begin{array}{c}0.02 \pm 0.15 \\
(0-1)\end{array}$ & $\begin{array}{c}0.10 \pm 0.40 \\
(0-2)\end{array}$ & $\begin{array}{c}0.03 \pm 0.21 \\
(0-2)\end{array}$ & 0 & 0 & $\begin{array}{c}0.02 \pm 0.16 \\
(0-2)\end{array}$ \\
\hline Lamellodiscus virgula & $\begin{array}{l}1.90 \pm 8.81 \\
(0-52)\end{array}$ & $\begin{array}{l}0.03 \pm 0.23 \\
(0-2)\end{array}$ & $\begin{array}{c}21.67 \pm 119.45 \\
(0-772)\end{array}$ & $\begin{array}{l}5.20 \pm 11.82 \\
(0-47)\end{array}$ & $\begin{array}{l}5.58 \pm 54.39 \\
(0-772)\end{array}$ & $\begin{array}{c}1.61 \pm 12.03 \\
(0-90)\end{array}$ & $\begin{array}{l}0.52 \pm 4.85 \\
\quad(0-45)\end{array}$ & $\begin{array}{l}3.69 \pm 42.21 \\
(0-772)\end{array}$ \\
\hline \multicolumn{9}{|c|}{ 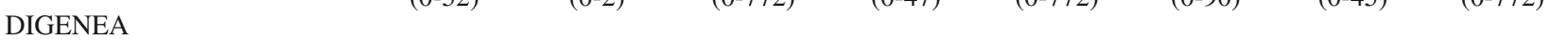 } \\
\hline Accacladocoelium petasiporum & 0 & 0 & 0 & 0 & 0 & 0 & $\begin{array}{c}0.03 \pm 0.32 \\
(0-3)\end{array}$ & $\begin{array}{c}0.01 \pm 0.16 \\
(0-3)\end{array}$ \\
\hline Brachyenteron helicoleni & $\begin{array}{c}2.19 \pm 13.57 \\
(0-88)\end{array}$ & $\begin{array}{c}0.02 \pm 0.21 \\
(0-2)\end{array}$ & $\begin{array}{c}16.76 \pm 82.72 \\
(0-533)\end{array}$ & $\begin{array}{c}1.50 \pm 5.64 \\
(0-28)\end{array}$ & $\begin{array}{c}4.09 \pm 38.10 \\
(0-533)\end{array}$ & 0 & 0 & $\begin{array}{c}2.42 \pm 29.36 \\
(0-533)\end{array}$ \\
\hline Derogenes varicus & 0 & $\begin{array}{c}0.02 \pm 0.15 \\
(0-1)\end{array}$ & 0 & 0 & $\begin{array}{c}0.01 \pm 0.10 \\
(0-1)\end{array}$ & 0 & $\begin{array}{c}0.01 \pm 0.11 \\
(0-1)\end{array}$ & $\begin{array}{c}0.01 \pm 0.09 \\
(0-1)\end{array}$ \\
\hline Diphterostomum vividum & $\begin{array}{c}1.40 \pm 5.87 \\
(0-31)\end{array}$ & $\begin{array}{l}2.52 \pm 18.30 \\
(0-175)\end{array}$ & $\begin{array}{c}2.00 \pm 5.42 \\
(0-26)\end{array}$ & $\begin{array}{l}0.47 \pm 1.01 \\
(0-4)\end{array}$ & $\begin{array}{c}1.89 \pm 12.73 \\
(0-175)\end{array}$ & $\begin{array}{c}1.16 \pm 6.02 \\
(0-43)\end{array}$ & 0 & $\begin{array}{c}1.30 \pm 10.11 \\
(0-175)\end{array}$ \\
\hline Glomericirrus macrouri & 0 & $\begin{array}{c}0.01 \pm 0.10 \\
(0-1)\end{array}$ & 0 & 0 & $\begin{array}{c}0.00 \pm 0.07 \\
(0-1)\end{array}$ & 0 & 0 & $\begin{array}{c}0.00 \pm 0.05 \\
(0-1)\end{array}$ \\
\hline Hemiurus communis & $\begin{array}{l}0.05 \pm 0.22 \\
\quad(0-1)\end{array}$ & $\begin{array}{l}0.01 \pm 0.10 \\
(0-1)\end{array}$ & 0 & 0 & $\begin{array}{l}0.01 \pm 0.12 \\
(0-1)\end{array}$ & 0 & 0 & $\begin{array}{l}0.01 \pm 0.09 \\
(0-1)\end{array}$ \\
\hline Hemiuridae gen. sp. & 0 & $\begin{array}{l}0.01 \pm 0.10 \\
\quad(0-1)\end{array}$ & 0 & $\begin{array}{l}0.03 \pm 0.18 \\
(0-1)\end{array}$ & $\begin{array}{l}0.01 \pm 0.10 \\
\quad(0-1)\end{array}$ & 0 & 0 & $\begin{array}{l}0.01 \pm 0.08 \\
\quad(0-1)\end{array}$ \\
\hline Lecithocladium excisum & $\begin{array}{c}0.24 \pm 1.10 \\
(0-7)\end{array}$ & $\begin{array}{c}0.67 \pm 1.40 \\
(1-6)\end{array}$ & $\begin{array}{c}0.10 \pm 0.37 \\
(0-2)\end{array}$ & $\begin{array}{c}0.47 \pm 1.17 \\
(0-6)\end{array}$ & $\begin{array}{c}0.44 \pm 1.18 \\
(0-7)\end{array}$ & 0 & $\begin{array}{c}0.01 \pm 0.11 \\
(0-1)\end{array}$ & $\begin{array}{c}0.26 \pm 0.93 \\
(0-7)\end{array}$ \\
\hline Lepocreadium album & $\begin{array}{l}0.07 \pm 0.26 \\
(0-1)\end{array}$ & $\begin{array}{l}0.21 \pm 0.73 \\
(0-5)\end{array}$ & $\begin{array}{l}0.02 \pm 0.15 \\
(0-1)\end{array}$ & 0 & $\begin{array}{l}0.11 \pm 0.52 \\
(0-5)\end{array}$ & 0 & $\begin{array}{c}0.01 \pm 0.11 \\
(0-1)\end{array}$ & $\begin{array}{l}0.07 \pm 0.40 \\
(0-5)\end{array}$ \\
\hline Opecoelidae gen. sp. & $\begin{array}{l}0.02 \pm 0.15 \\
\quad(0-1)\end{array}$ & 0 & 0 & 0 & $\begin{array}{l}0.00 \pm 0.07 \\
(0-1)\end{array}$ & 0 & 0 & $\begin{array}{l}0.00 \pm 0.05 \\
(0-1)\end{array}$ \\
\hline Pachycreadium carnosum & 0 & 0 & 0 & 0 & 0 & $\begin{array}{l}0.02 \pm 0.13 \\
\quad(0-1)\end{array}$ & $\begin{array}{l}0.01 \pm 0.11 \\
(0-1)\end{array}$ & $\begin{array}{l}0.01 \pm 0.08 \\
(0-1)\end{array}$ \\
\hline Pycnadenoides senegalensis & $\begin{array}{l}0.02 \pm 0.15 \\
\quad(0-1)\end{array}$ & $\begin{array}{l}0.08 \pm 0.54 \\
(0-5)\end{array}$ & $\begin{array}{l}0.31 \pm 1.41 \\
\quad(0-9)\end{array}$ & 0 & $\begin{array}{l}0.10 \pm 0.74 \\
\quad(0-9)\end{array}$ & 0 & $\begin{array}{l}0.01 \pm 0.11 \\
\quad(0-1)\end{array}$ & $\begin{array}{l}0.06 \pm 0.57 \\
(0-9)\end{array}$ \\
\hline $\begin{array}{l}\text { CESTODA } \\
\text { Tetraphyllidea gen. sp. }\end{array}$ & 0 & 0 & $\begin{array}{c}0.02 \pm 0.15 \\
(0-1)\end{array}$ & 0 & $\begin{array}{c}0.00 \pm 0.07 \\
(0-1)\end{array}$ & $\begin{array}{c}0.02 \pm 0.13 \\
(0-1)\end{array}$ & $\begin{array}{c}0.01 \pm 0.11 \\
(0-1)\end{array}$ & $\begin{array}{c}0.01 \pm 0.09 \\
(0-1)\end{array}$ \\
\hline NEMATODA & & & & & & & & \\
\hline Anisakidae & $\begin{array}{c}12.50 \pm 11.93 \\
(1-48)\end{array}$ & $\begin{array}{c}9.93 \pm 14.06 \\
(0-85)\end{array}$ & $\begin{array}{c}43.71 \pm 83.40 \\
(1-449)\end{array}$ & $\begin{array}{c}6.77 \pm 14.14 \\
(0-76)\end{array}$ & $\begin{array}{c}16.88 \pm 41.52 \\
(0-449)\end{array}$ & $\begin{array}{c}13.68 \pm 22.06 \\
(0-125)\end{array}$ & $\begin{array}{c}1.15 \pm 1.91 \\
(0-10)\end{array}$ & $\begin{array}{c}12.48 \pm 33.76 \\
(0-449)\end{array}$ \\
\hline Camallanus sp. & 0 & 0 & $\begin{array}{l}0.02 \pm 0.15 \\
(0-1)\end{array}$ & 0 & $\begin{array}{l}0.00 \pm 0.07 \\
(0-1)\end{array}$ & 0 & 0 & $\begin{array}{l}0.00 \pm 0.05 \\
(0-1)\end{array}$ \\
\hline Philometra filiformis & 0 & $\begin{array}{l}0.01 \pm 0.10 \\
\quad(0-1)\end{array}$ & 0 & 0 & $\begin{array}{l}0.00 \pm 0.07 \\
(0-1)\end{array}$ & 0 & 0 & $\begin{array}{l}0.00 \pm 0.05 \\
\quad(0-1)\end{array}$ \\
\hline $\begin{array}{l}\text { ACANTHOCEPHALA } \\
\text { Bolbosoma sp. }\end{array}$ & 0 & $\begin{array}{c}0.02 \pm 0.15 \\
(0-1)\end{array}$ & $\begin{array}{c}0.05 \pm 0.22 \\
(0-1)\end{array}$ & $\begin{array}{c}0.03 \pm 0.18 \\
(0-1)\end{array}$ & $\begin{array}{c}0.02 \pm 0.15 \\
(0-1)\end{array}$ & $\begin{array}{c}0.13 \pm 0.47 \\
(0-3)\end{array}$ & $\begin{array}{c}0.21 \pm 0.53 \\
(0-3)\end{array}$ & $\begin{array}{c}0.09 \pm 0.35 \\
(0-3)\end{array}$ \\
\hline Rhadinorhynchus pristis & $\begin{array}{l}0.02 \pm 0.15 \\
\quad(0-1)\end{array}$ & $\begin{array}{l}0.01 \pm 0.10 \\
(0-1)\end{array}$ & $\begin{array}{l}0.05 \pm 0.22 \\
(0-1)\end{array}$ & $\begin{array}{l}0.07 \pm 0.37 \\
(0-2)\end{array}$ & $\begin{array}{l}0.03 \pm 0.20 \\
(0-2)\end{array}$ & 0 & $\begin{array}{l}0.28 \pm 1.55 \\
(0-12)\end{array}$ & $\begin{array}{l}0.09 \pm 0.79 \\
(0-12)\end{array}$ \\
\hline $\begin{array}{l}\text { CRUSTACEA } \\
\text { Aega antillensis }\end{array}$ & 0 & (2) & ( & 0 & [ & 0 & $\begin{array}{c}0.01 \pm 0.11 \\
(0-1)\end{array}$ & $\begin{array}{c}0.00 \pm 0.05 \\
(0-1)\end{array}$ \\
\hline Aega deshaysiana & 0 & 0 & 0 & 0 & 0 & $\begin{array}{l}0.11 \pm 0.45 \\
\quad(0-3)\end{array}$ & 0 & $\begin{array}{c}0.02 \pm 0.19 \\
(0-3)\end{array}$ \\
\hline Argulus sp. & 0 & 0 & 0 & 0 & 0 & 0 & $\begin{array}{c}0.01 \pm 0.12 \\
(0-1)\end{array}$ & $\begin{array}{c}0.00 \pm 0.05 \\
(0-1)\end{array}$ \\
\hline Gnathia sp. & 0 & $\begin{array}{c}0.76 \pm 3.88 \\
(0-31)\end{array}$ & 0 & 0 & $\begin{array}{l}0.34 \pm 2.62 \\
(0-31)\end{array}$ & $\begin{array}{c}0.48 \pm 1.60 \\
(0-11)\end{array}$ & $\begin{array}{c}2.41 \pm 14.58 \\
(0-133)\end{array}$ & $\begin{array}{c}0.87 \pm 7.57 \\
(0-133)\end{array}$ \\
\hline Hatschekia pagellibogneravei & 0 & 0 & 0 & 0 & 0 & $\begin{array}{c}34.00 \pm 62.42 \\
(0-363)\end{array}$ & $\begin{array}{c}0.24 \pm 1.12 \\
(0-7)\end{array}$ & $\begin{array}{l}5.53 \pm 27.82 \\
(0-363)\end{array}$ \\
\hline Peniculus fistula & 0 & $\begin{array}{l}0.01 \pm 0.10 \\
\quad(0-1)\end{array}$ & 0 & $\begin{array}{l}0.03 \pm 0.18 \\
\quad(0-1)\end{array}$ & $\begin{array}{l}0.01 \pm 0.10 \\
\quad(0-1)\end{array}$ & 0 & 0 & $\begin{array}{c}0.01 \pm 0.08 \\
(0-1)\end{array}$ \\
\hline Rocinela danmoniensis & 0 & $\begin{array}{l}0.01 \pm 0.10 \\
\quad(0-1)\end{array}$ & $\begin{array}{l}0.02 \pm 0.15 \\
\quad(0-1)\end{array}$ & 0 & $\begin{array}{l}0.01 \pm 0.10 \\
\quad(0-1)\end{array}$ & $\begin{array}{l}0.05 \pm 0.23 \\
\quad(0-1)\end{array}$ & 0 & $\begin{array}{l}0.01 \pm 0.12 \\
\quad(0-1)\end{array}$ \\
\hline
\end{tabular}

ties were performed using a chi-square test (Hermida et al. 2012)

\section{RESULTS}

A total of 36 parasite species were detected in $\mathrm{Pa}$ gellus bogaraveo from Portuguese waters, including nine ectoparasite and 27 endoparasite species (Table
1). A sub-sample of anisakids was molecularly identified to species level, revealing the occurrence of nine anisakid nematode species: Anisakis simplex sensu stricto, A. pegreffii, A. ziphidarum, A. typica, Anisakis sp. PB-2009, Anisakis sp. PB-2010, A. physeteris, Hysterothylacium sp. PB-2010, and Contracaecum sp. PB2010; furthermore, A. simplex s.s. $\times$ A. pegreffii hybrid genotypes were also detected (Hermida et al. 2012). 
TABLE 3. - Parasite species selected as biological tags for the identification of Pagellus bogaraveo stocks in Portuguese waters of the northeast Atlantic and significant differences detected between localities/regions.

\begin{tabular}{|c|c|c|c|c|c|c|c|}
\hline & Matosinhos & Figueira da Foz & Peniche & Sagres & Madeira & Azores & Significant differences \\
\hline Diphterostomum vividum $^{1}$ & $\begin{array}{c}14.3 \\
\mathrm{ab}\end{array}$ & $\begin{array}{c}17.4 \\
\mathrm{ab}\end{array}$ & $\begin{array}{c}23.8 \\
\mathrm{~b}\end{array}$ & $\begin{array}{c}23.3 \\
\mathrm{ab}\end{array}$ & $\begin{array}{c}8.9 \\
\mathrm{a}\end{array}$ & $\begin{array}{c}0.0 \\
\mathrm{c}\end{array}$ & $\begin{array}{l}\text { Absence in Azores significantly } \\
\text { different from other localities }\end{array}$ \\
\hline Anisakis simplex s.1. ${ }^{2}$ & $\begin{array}{c}100 \\
\mathrm{c}\end{array}$ & $\begin{array}{c}100 \\
\mathrm{c}\end{array}$ & $\begin{array}{c}97 \\
\mathrm{c}\end{array}$ & $\begin{array}{c}89 \\
\mathrm{c}\end{array}$ & $\begin{array}{c}12 \\
\mathrm{a}\end{array}$ & $\begin{array}{c}55 \\
\mathrm{~b}\end{array}$ & $\begin{array}{l}\text { No significant differences among } \\
\text { mainland localities. Madeira and } \\
\text { Azores significantly different both } \\
\text { from the mainland and each other }\end{array}$ \\
\hline A. physeteris ${ }^{2}$ & $\begin{array}{l}0 \\
\mathrm{a}\end{array}$ & $\begin{array}{l}0 \\
\mathrm{a}\end{array}$ & $\begin{array}{l}0 \\
\mathrm{a}\end{array}$ & $\begin{array}{l}3 \\
\mathrm{a}\end{array}$ & $\begin{array}{c}12 \\
\mathrm{a}\end{array}$ & $\begin{array}{c}42 \\
b\end{array}$ & $\begin{array}{l}\text { Relative abundance significantly } \\
\text { higher in the Azores }\end{array}$ \\
\hline Anisakis sp. PB-2010 2 & $\begin{array}{l}0 \\
\mathrm{a}\end{array}$ & $\begin{array}{l}0 \\
\mathrm{a}\end{array}$ & $\begin{array}{l}0 \\
\mathrm{a}\end{array}$ & $\begin{array}{l}0 \\
\mathrm{a}\end{array}$ & $\begin{array}{l}55 \\
\mathrm{~b}\end{array}$ & $\begin{array}{l}0 \\
\mathrm{a}\end{array}$ & $\begin{array}{l}\text { Occurrence only in Madeira with } \\
\text { significantly high relative abundance }\end{array}$ \\
\hline \multirow[t]{2}{*}{ Bolbosoma sp. ${ }^{1}$} & 0.0 & 2.2 & 4.8 & 3.3 & \multirow{2}{*}{$\begin{array}{c}8.9 \\
b\end{array}$} & \multirow{2}{*}{$\begin{array}{c}16.3 \\
b\end{array}$} & \multirow{2}{*}{$\begin{array}{l}\text { Prevalence significantly lower in the } \\
\text { mainland compared with Madeira and } \\
\text { Azores }\end{array}$} \\
\hline & \multicolumn{4}{|c|}{$\begin{array}{c}2.4^{3} \\
a\end{array}$} & & & \\
\hline
\end{tabular}

${ }^{1}$ Prevalence $(\%) ;{ }^{2}$ relative abundance $(\%)$ (Hermida et al. 2012); ${ }^{3}$ mainland prevalence

Prevalence values detected at each of the four mainland localities and the two Atlantic archipelagos of Azores and Madeira, as well as significant differences, are presented in Table 1. The highest prevalences were obtained for anisakid nematodes at all the studied localities, and also for the copepod Hatschekia pagellibogneravei in $P$. bogaraveo from Madeira. Mean abundances are presented in Table 2 .

There were significant differences between mainland localities in the prevalence of the digenean Lecithocladium excisum, but no clear gradient or distribution pattern was discerned. Anisakid prevalence also varied significantly between mainland localities, with samples from Matosinhos and Peniche exhibiting the highest prevalence and the sample from Sagres the lowest. Again there was no clear gradient or pattern to this variation. Although no prevalence values were obtained for different anisakid nematode species, significant differences were detected in the relative abundance of Anisakis simplex s.s. and A. pegreffii between mainland localities (Hermida et al. 2012). Furthermore, the species Anisakis ziphidarum, A. physeteris, and Hysterothylacium sp. PB-2010 showed differences in occurrence within mainland waters (A. ziphidarum occurred at Peniche and Sagres, whereas the latter two occurred only at Sagres) but with very low relative abundance. Relative abundance of A. simplex s.l. (which included A. simplex s.s., A. pegreffii, and hybrids thereof) was very high at all mainland localities, exhibiting no significant differences within this region (Hermida et al. 2012).

Significant differences were detected in the prevalence of several parasite species when comparing the three regions (mainland Portugal, Madeira and the Azores). Among ectoparasites, there were significant differences in the prevalence of the diplectanid monogenean Lamellodiscus virgula, the copepod Hatschekia pagellibogneravei, and the isopod Gnathia sp. The other detected monogenean, Choricotyle chrysophryi, occurred only in mainland waters, but prevalence values were too low to allow statistical analysis.
Among endoparasites, significant differences were detected in the prevalence of the digeneans $D$. vividum and $L$. excisum when comparing the three regions. The zoogonid D. vividum occurred at all localities except the Azores, whereas the hemiurid L. excisum occurred at all localities except Madeira, but prevalence was lower at the Azores than at mainland localities. Furthermore, another zoogonid, B. helicoleni, occurred at all mainland localities and not in the archipelagos; however the prevalence values detected did not permit statistical analysis. The A. simplex s.l. complex also exhibited significant differences between the three regions, with relative abundance being very high at all mainland localities, lower at the Azores, and much lower at Madeira. Two other anisakid species also showed clear and significant regional differences: A. physeteris had a significantly higher relative abundance in the Azores, and Anisakis sp. PB-2010 occurred only in blackspot seabream from Madeira, with a statistically significant high relative abundance (Hermida et al. 2012). Finally, the juvenile acanthocephalan Bolbosoma sp. had a significantly higher prevalence in both archipelagos when compared with mainland waters.

\section{DISCUSSION}

\section{Parasite fauna of Pagellus bogaraveo}

The parasite fauna of blackspot seabream from Portuguese waters was found to be diverse, with a predominance of nematode and digenean species. The diversity of digeneans detected and the near-absence of cestodes may indicate a preponderance of benthic feeding, since digeneans rely on benthic invertebrates as intermediate hosts, whereas cestodes tend to be transmitted pelagically (Marcogliese 2002). The proportion of species from each taxonomic group was comparable to that detected in another benthopelagic sparid fish, the bogue Boops boops, from Galicia (Pérez-del Olmo et al. 2010), with several parasites being shared by both fishes. Infection levels, however, were very different, 
with $B$. boops having much higher digenean prevalences, and $P$. bogaraveo much higher prevalences of anisakid nematodes. These differences are likely to reflect the different feeding habits of the two fishes since, unlike $P$. bogaraveo, $B$. boops is a suction feeder without active prey selection (Morato et al. 2001, Pérez-del Olmo et al. 2007).

\section{Selection of parasite tags}

Lester (1990) considered the life span to be the single most important criterion for the suitability of a parasite as a biological tag. Following this recommendation, it is evident that the most suitable tags from the parasites detected are those that occur as juveniles, namely anisakid nematodes and the acanthocephalan Bolbosoma sp. Anisakid nematodes have often been used as biological tags in fish stock identification studies (MacKenzie et al. 2008, Sequeira et al. 2010, Garcia et al. 2011, among others), and are recognized as being particularly appropriate for this purpose due to their prolonged permanence in the host. Within the anisakid nematodes, both Anisakis simplex s.s. and Anisakis pegreffii, belonging to the Anisakis simplex s.l. complex, showed significant differences in relative abundance between mainland localities. These differences, however, did not follow any pattern or gradient like the one observed for example by Mattiucci et al. (2008) in Trachurus trachurus from the same region. Furthermore, these species are not reproductively isolated (Martín-Sánchez et al. 2005), producing A. simplex s.s. x A. pegreffii hybrids, which were also encountered in blackspot seabream both from mainland waters and from the Azores (Hermida et al. 2012), so their taxonomic status is unclear at present. A. simplex s.1., in contrast, showed uniformly high relative abundance at all mainland localities and significant differences in both archipelagos, making it a potentially useful biological tag for P. bogaraveo in the northeast Atlantic, in addition to A. physeteris and Anisakis sp. PB-2010.

Juvenile acanthocephalans are also widely recognized as appropriate parasite tags. Although acanthocephalans tend to be short-lived as adults, they have much longer life spans in intermediate and paratenic hosts (Kennedy 1985, 2006). Furthermore, encysted acanthocephalans may remain in an identifiable form in the host even after they die, since the hard structures (spines and hooks) are still recognizable. Moreover, although acanthocephalans are known to affect the behaviour of invertebrate intermediate hosts in order to facilitate transmission, there is no evidence of any effect on the behaviour of vertebrate paratenic hosts; nor do they normally cause any severe pathology in these hosts (Kennedy 2006). Indeed, many stock identification studies have successfully used juvenile acanthocephalans such as Corynosoma sp. (Timi and Lanfranchi 2009, McClelland and Melendy 2011), Bolbosoma vasculosum (Santos et al. 2009) and Bol- bosoma sp. (George-Nascimento and Arancibia 1992) as biological tags. Since Bolbosoma sp. showed significant differences in prevalence between mainland/ Madeira and the Azores, it was also considered a good biological tag for blackspot seabream.

Although the life span of adult digeneans in their fish hosts is not well known, it is generally accepted that most digeneans survive in their definitive hosts for at least several months (Sandground 1936). Also, being endoparasites they are relatively sheltered from sudden changes in abiotic conditions that might be encountered if the fish migrate to different areas. Therefore, they have also been used by some authors as biological tags (e.g. Boje et al. 1997). Diphterostomum vividum is a specific parasite of blackspot seabream that occurred at all studied localities except in the Azores, a difference which was statistically significant. Therefore this species should also be useful as an indicator. The life cycle of $D$. vividum is not fully known, but other Diphterostomum species use gastropods such as Nassarius reticulatus as first intermediate hosts, and bivalves such as Cerastoderma edule and Mytilus galloprovincialis as second intermediate hosts (Bray and Gibson 1986, Pina et al. 2009, Francisco et al. 2011). These species have low vagility, which may contribute to the restricted geographical distribution of this parasite.

Ectoparasites, on the contrary, are more vulnerable to water temperature and other abiotic conditions, and some species can easily be lost from the host. Therefore, it seemed more prudent to disregard the ectoparasite species detected as potential biological tags.

\section{Biogeographical patterns of distribution at the re- gional level}

In Table 3, a summary of the significant differences at regional level is presented. The mainland sample was clearly separated from both Madeira and the Azores by significantly higher relative abundance of $A$. simplex s.l. and significantly lower prevalence of Bolbosoma sp. The Madeiran sample was characterized by the occurrence, with high relative abundance, of Anisakis sp. PB-2010 and also by the significantly lower relative abundance of $A$. simplex s.l. The Azorean sample was mainly characterized by the significantly higher relative abundance of $A$. physeteris and the absence of D. vividum.

The higher prevalence of $D$. vividum in mainland samples is likely to reflect differences in benthic fauna. The distribution of trematodes is conditioned first and foremost by the distribution of their intermediate hosts, for which they may be strongly specific. It is likely that some benthic invertebrates that act as intermediate hosts of digeneans are more abundant on the continental shelf and slope than in oceanic environments. The zoogonid $D$. vividum is strictly specific to $P$. bogaraveo and thus far has only been reported from the British Isles (Nicoll 1912, 1914, Bray 1986, Bray and Gibson 1986). Its intermediate hosts are unknown. However its 
geographical range does not seem to extend to Azorean waters.

The geographical distribution of anisakid nematodes is conditioned not only by the availability of intermediate hosts, but especially by the presence of appropriate definitive hosts in which the parasite can complete its life cycle. Different species of marine mammals serve as definitive hosts of Anisakis spp., and the distribution of the former necessarily restricts the distribution of the latter. The definitive host of $A$. physeteris is the sperm whale, Physeter macrocephalus, of which there is a large and stable population in the Azores (Pinela et al. 2009) that would explain the significantly higher relative abundance of this anisakid in that region (Hermida et al. 2012). Significantly, higher prevalence of this anisakid has also been detected in Helicolenus dactylopterus from the Azores in comparison with both Madeira and mainland waters (Sequeira et al. 2010).

The high infection levels by $A$. simplex s.l. seem to be characteristic of the Atlantic part of the Iberian Peninsula, and have been detected in numerous other fish from this region (Abollo et al. 2003, Marques et al. 2006, Mattiucci et al. 2008, Sequeira et al. 2010). The significantly lower relative abundance of this species complex in fish from the Azores, and the again significantly lower relative abundance in Madeira, make it a good indicator of $P$. bogaraveo provenance.

Particularly striking, in the case of the Madeiran sample, were the very high levels of infection by the anisakid nematode Anisakis sp. PB-2010, which was not detected elsewhere but showed remarkable genetic similarity, and is probably conspecific with Anisakis sp. HC-2005 detected by Kijewska et al. (2009) in fish from the African shelf (Hermida et al. 2012). The definitive host of Anisakis sp. PB-2010 is unknown, but a variety of marine mammals are present in the waters around Madeira (Santos-Reis and Mathias 1996), which also explains the higher diversity of anisakid nematodes in this area (Hermida et al. 2012). Furthermore, its absence from the other localities suggests a restricted distribution of this nematode, which might not be able to complete its life cycle elsewhere, making it an excellent indicator species for $P$. bogaraveo from this region.

Finally, the juvenile acanthocephalan Bolbosoma sp. was significantly more prevalent in both archipelagos than in mainland waters. Santos et al. (2009) found a significantly higher prevalence of Bolbosoma vasculosum in the black scabbardfish, Aphanopus carbo, from those two archipelagos in comparison with mainland waters, and Shukhgalter (2004) detected Bolbosoma sp. in Scomber japonicus from the Azores, but not in Morocco or Mauritania. This suggests that Bolbosoma sp. is mostly present in oceanic habitats, and less frequently on the continental shelf and slope. This might be due to the distribution patterns of both its intermediate hosts, which are thought to be pelagic crustaceans, and the marine mammals that are used as definitive hosts (Costa et al. 2000).

\section{Insight into blackspot seabream stocks}

Infection levels of selected parasite tags within mainland waters were remarkably homogeneous, whereas differences between mainland waters, Madeira, and the Azores were clear and statistically significant. Taken in conjunction, these results clearly point to the existence of three stocks of $P$. bogaraveo in the study area: one at mainland Portugal, one at the Azores, and one at Madeira.

The separation of the Azorean population from those from mainland and Madeiran waters is partly backed by genetic studies. Though there seems to be very little genetic variability in this species, possibly due to a past bottleneck (Bargelloni et al. 2003, Stockley et al. 2005, Patarnello et al. 2007), Stockley et al. (2005) detected low but significant genetic differentiation in mitochondrial DNA between populations at a regional level, but only between the Azores vs. the mainland and Madeira. The dispersal of benthopelagic fish is limited by the existence of topographical barriers, and the ocean basin that lies between the European continental shelf and the Azores archipelago is likely to constitute a formidable obstacle for $P$. bogaraveo (Piñera et al. 2007), whereas Madeira is closer to the mainland. Moreover, the existence of several seamounts that can act as "stepping stones" for benthopelagic species (Gubbay 2003) is likely to facilitate contact between these two regions. Thus, the lack of genetic differentiation between $P$. bogaraveo populations from Madeira and the mainland is not surprising.

Lack of genetic differentiation, however, does not necessarily imply panmixia, especially in a species with unusually low levels of genetic variability. Even a small number of migrant fish per generation can be sufficient to prevent detectable heterogeneity in neutral genetic markers (Carvalho and Hauser 1994). Yet fish populations that are not strictly reproductively isolated can still constitute appropriate fishery management units, responding independently to the effects of exploitation (Pawson and Jennings 1996). The results of this study point to the existence of separate $P$. bogaraveo stocks at Madeira and mainland Portugal.

In conclusion, differences in the parasitofauna of blackspot seabream from the Portuguese Exclusive Economic Zone (EEZ) point to the existence of three separate stocks, one in the Azores region (ICES Area X), one in continental shelf/slope waters (ICES Area IXa), and one in the waters around Madeira (sub-area 1.2 of FAO 34, central-eastern Atlantic). However, a more thorough study should be carried out for this species, involving larger sample sizes and also incorporating other sampling localities within its distribution range.

\section{ACKNOWLEDGEMENTS}

The authors are grateful to Fernando Alexandre for proof-reading and helping to improve the manuscript. This research was partially supported by FCT - Founda- 
tion for Science and Technology (M.H., Grant number SFRH/BD/47767/2008) and by the European Regional Development Fund (ERDF) through the COMPETE - Operational Competitiveness Programme and national funds through FCT - Foundation for Science and Technology, under the project "PEst-C/MAR/ LA0015/2011.

\section{REFERENCES}

Abaunza P., Murta A.G., Campbell N., Cimmaruta R., Comesaña A.S., Dahle G., García Santamaría M.T., Gordo L.S., Iversen S.A., MacKenzie K., Magoulas A., Mattiucci S., Molloy J.,Nascetti G., Pinto A.L., Quinta R., Ramos P., Sanjuan A., Santos A.T., Stransky C., Zimmermann C. 2008. Stock identity of horse mackerel (Trachurus trachurus) in the Northeast Atlantic and Mediterranean Sea: Integrating the results from different stock identification approaches. Fish. Res. 89: 196-209.

Abollo E., Paggi L., Pascual S., D’Amelio S. 2003. Occurrence of recombinant genotypes of Anisakis simplex s.s. and Anisakis pegreffii (Nematoda: Anisakidae) in an area of sympatry. Infect. Genet. Evol. 3: 175-181.

Bargelloni L., Alarcon J.A., Alvarez M.C., Penzo E., Magoulas A., Reis C., Patarnello T. 2003. Discord in the family Sparidae: divergent phylogeographical patterns across the Atlantic-Mediterranean divide. J. Evol. Biol. 16: 1149-1158.

Boje J., Riget F., Køie M. 1997. Helminth parasites as biological tags in population studies of Greenland halibut (Reinhardtius hippoglossoides (Walbaum)), in the north-west Atlantic. ICES J. Mar. Sci. 54: 886-895.

Bray R.A. 1986. A revision of the family Zoogonidae Odhner, 1902 (Platyhelminthes: Digenea): Introduction and subfamily Zoogoninae. Syst. Parasitol. 9: 3-28.

Bray R.A., Gibson D.I. 1986. The Zoogonidae (Digenea) of fishes from the north-east Atlantic. Bull. Brit. Mus. Nat. Hist. (Zool.) 51: 127-206.

Bush A.O., Lafferty K.D., Lotz J.M., Shostak A.W. 1997. Parasitology meets ecology on its own terms: Margolis et al. revisited. $J$. Parasitol. 83: 575-583.

Carvalho G.R., Hauser L. 1994. Molecular genetics and the stock concept in fisheries. Rev. Fish Biol. Fisher. 4: 326-350.

Costa G., Chubb J.C., Veltkamp C.J. 2000. Cystacanths of Bolbosoma vasculosum in the black scabbard fish Aphanopus carbo, oceanic horse mackerel Trachurus picturatus and common dolphin Delphinus delphis from Madeira, Portugal. J. Helminthol. 74: 113-120.

Francisco C.J., Almeida A., Castro A.M., Pina S., Russell-Pinto F., Rodrigues P., Santos M.J. 2011. Morphological and molecular analysis of metacercariae of Diphtherostomum brusinae (Stossich, 1988) Stossich, 1903 from a new bivalve host Mytilus galloprovincialis. J. Helminthol. 85: 179-184.

Garcia A., Mattiucci S., Damiano S., Santos M.N., Nascetti G. 2011. Metazoan parasites of swordfish, Xiphias gladius (Pisces: Xiphiidae) from the Atlantic Ocean: implications for host stock identification. ICES J. Mar. Sci. 68: 175-182.

George-Nascimento M., Arancibia H. 1992. Stocks ecológicos del jurel (Trachurus symmetricus murphyi Nichols) en tres zonas de pesca frente a Chile, detectados mediante comparación de su fauna parasitária e morfometría. Rev. Chil. Hist. Nat. 65: 453-470.

Gubbay S. 2003. Seamounts of the North-East Atlantic. OASIS, Hamburg and WWF Germany, Frankfurt am Main, 38 pp.

Hermida M., Mota R., Pacheco C.C., Santos C.L., Cruz C., Saraiva A., Tamagnini P. 2012. Infection levels and diversity of anisakid nematodes in blackspot seabream, Pagellus bogaraveo, from Portuguese waters. Parasitol. Res. 110: 1919-1928.

Hermida M., Cruz C., Saraiva A. 2013. Ectoparasites of the blackspot seabream Pagellus bogaraveo (Teleostei: Sparidae) from Portuguese waters of the north-east Atlantic. J. Mar. Biol. Assoc. UK, 93(2): 503-510.

Hermida M., Cruz C., Saraiva A. In press. Gastrointestinal helminth communities of the blackspot seabream Pagellus bogaraveo (Teleostei: Sparidae) from Portuguese north-east Atlantic waters. J. Helminthol.
Kennedy C.R. 1985. Regulation and dynamics of acanthocephalan populations. In: Crompton D.W.T., Nickol B.B. (eds), Biology of the Acanthocephala. Cambridge University Press, pp. 385-416.

Kennedy C.R. 2006. Ecology of the Acanthocephala. Cambridge University Press, Cambidge. 249 pp.

Kijewska A., Dzido J., Schukhgalter O., Rokicki J. 2009. Anisakid parasites of fishes caught on the African shelf. J. Parasitol. 95: 639-645.

Lemos A., Freitas A.I., Fernandes A.T., Gonçalves R., Jesus J., Andrade C., Brehm A. 2006. Microsatellite variability in natural populations of the blackspot seabream Pagellus bogaraveo (Brünnich, 1768): a database to access parentage assignment in aquaculture. Aquac. Res. 37: 1028-1033.

Lester R.J.G. (1990). Reappraisal of the use of parasites for fish stock identification. Aust. J. Mar. Fresh. Res. 41: 855-864.

Lester R.J.G., MacKenzie K. 2009. The use and abuse of parasites as stock markers for fish. Fish. Res. 97: 1-2.

Lorance P. 2011. History and dynamics of the overexploitation of the blackspot sea bream (Pagellus bogaraveo) in the Bay of Biscay. ICES J. Mar. Sci. 68: 290-301.

MacKenzie K., Abaunza P. 1998. Parasites as biological tags for stock discrimination of marine fish: a guide to procedures and methods. Fish. Res. 38: 45-56.

MacKenzie K., Abaunza P. 2005. Parasites as Biological Tags. In: Cadrin S.X., Friedland K.D., Waldman J.R. (eds) Stock Identification Methods: Applications in Fishery Science. Elsevier/ Academic Press, pp. 211-226.

MacKenzie K., Campbell N., Mattiucci S., Ramos P., Pinto A.L., Abaunza P. 2008. Parasites as biological tags for stock identification of Atlantic horse mackerel Trachurus trachurus L. Fish. Res. 89: 136-145.

Marcogliese D.J. 2002. Food webs and the transmission of parasites to marine fish. Parasitology 12: S83-S99.

Marques J.F., Cabral H.N., Busi M., D’ Amelio S. 2006. Molecular identification of Anisakis species from Pleuronectiformes off the Portuguese coast. J. Helminthol. 80: 47-51.

Martín-Sánchez J., Artacho-Reinoso M.E., Díaz-Gavilán M., Valero-López A. 2005. Structure of Anisakis simplex s.1. populations in a region sympatric for A. pegreffii and A. simplex s.s. Absense of reproductive isolation between both species. Mol. Biochem. Parasit. 141: 155-162.

Mattiucci S., Farina V., Campbell N., MacKenzie K., Ramos P., Pinto A.L., Abaunza P., Nascetti G. 2008. Anisakis spp. larvae (Nematoda: Anisakidae) from Atlantic horse mackerel: their genetic identification and use as biological tags for host stock characterization. Fish. Res. 89: 146-151.

McClelland G., Melendy J. 2011. Use of parasites as tags in delineating stocks of Atlantic cod (Gadus morhua) from the southern Gulf of St. Lawrence and the Cape Breton Shelf. Fish. Res. 107: 233-238.

Menezes G.M., Sigler M.F., Silva H.M., Pinho M.R. 2006. Structure and zonation of demersal fish assemblages off the Azores Archipelago (mid-Atlantic). Mar. Ecol. Prog. Ser. 324: 241-260.

Morato T., Solà E., Grós M.P., Menezes G. 2001. Feeding habits of two congener species of seabreams, Pagellus bogaraveo and Pagellus acarne, off the Azores (Northeastern Atlantic) during Spring of 1996 and 1997. Bull. Mar. Sci. 69: 1073-1087.

Nicoll W. 1912. On two trematode parasites from British foodfishes. Parasitology 5: 197-202.

Nicoll W. 1914. The trematode parasites of fishes from the English Channel. J. Mar. Biol. Assoc. UK 10: 466-505.

Palma J., Andrade J.P. 2004. Morphological study of Pagrus pagrus, Pagellus bogaraveo, and Dentex dentex (Sparidae) in the eastern Atlantic and the Mediterranean Sea. J. Mar. Biol. Assoc. UK 84: 449-454.

Patarnello T., Volckaert A.M.J., Castilho R. 2007. Pillars of Hercules: is the Atlantic-Mediterranean transition a phylogeographical break? Mol. Ecol. 16: 4426-4444.

Pawson M.G., Jennings S. 1996. A critique of methods for stock identification in marine capture fisheries. Fish. Res. 25: 203-217.

Pérez-del Olmo A., Raga J.A., Kostadinova A., Fernández M. 2007. Parasite communities in Boops boops (L.) (Sparidae) after the Prestige oil-spill: Detectable alterations. Mar. Pollut. Bull. 54: 266-276.

Pérez-del Olmo A., Montero F.E., Fernández M., Barrett J., Raga 
J.A., Kostadinova A. 2010. Discrimination of fish populations using parasites: Random Forests on a 'predictable' host-parasite system. Parasitology 137: 1833-1847.

Pina S., Tajdari J., Russell-Pinto F., Rodrigues P. 2009. Morphological and molecular studies on life cycle stages of Diphtherosto mum brusinae (Digenea: Zoogonidae) from northern Portugal. J. Helminthol. 83: 321-331.

Pinela A.M., Quérouil S., Magalhães S., Silva M.A., Prieto P. Matos J.A., Santos R.S. 2009. Population genetics and social organization of the sperm whale (Physeter macrocephalus) in the Azores inferred by microsatellite analysis. Can. J. Zool. 87: 802-813.

Piñera J.A., Blanco G., Vázquez E., Sánchez J.A. 2007. Genetic diversity of blackspot seabream (Pagellus bogaraveo) populations off Spanish Coasts: a preliminary study. Mar. Biol. 151: 2153-2158.

Poulin R. 2006. Variation in infection parameters among populations within parasite species: Intrinsic properties versus local factors. Int. J. Parasitol. 36: 877-885.

Sandground J.H. 1936. On the potential longevity of various helminths with a record for a species of Trichostrongylus in man. J. Parasitol. 22: 464-470.

Santos M.J., Saraiva A., Cruz C., Eiras J.C., Hermida M., Ventura C., Soares J.P. 2009. Use of parasites as biological tags in stock identification of the black scabbardfish, Aphanopus carbo Lowe, 1839 (Osteichthyes: Trichiuridae) from Portuguese waters. Sci. Mar. 73S2: 55-62.

Santos-Reis M., Mathias M.L. 1996. The historical and recent dis- tribution and status of mammals in Portugal. Hystrix 8: 75-89.

Sequeira V., Gordo L.S., Neves A., Paiva R.B., Cabral H.N., Marques J.F. 2010. Macroparasites as biological tags for stock identification of the bluemouth, Helicolenus dactylopterus (Delaroche, 1809) in Portuguese waters. Fish. Res. 106: 321-328.

Shukhgalter O.A. 2004. [The parasite fauna of the chub mackerel (Scombridae: Scomber japonicus Houttuyn, 1782) in the central-eastern Atlantic (Atlantic coast of the Northern Africa and the Azores Archipelago banks)] (article in Russian). Parazitologiia 38: 160-170.

Spedicato M.T., Greco S., Sophronidis K., Lembo G., Giordano D., Argyri A. 2002. Geographical distribution, abundance and some population characteristics of the species of the genus Pagellus in different areas of the Mediterranean. Sci. Mar. 66S2: 65-82.

Stockley B., Menezes G., Pinho M.R., Rogers A.D. 2005. Genetic population structure in the black-spot sea bream (Pagellus bogaraveo Brünnich, 1768) from the NE Atlantic. Mar. Biol. 146: 793-804.

Timi J.T., Lanfranchi A.L. 2009. The metazoan parasite communities of the Argentinean sandperch Pseudopersis semifasciata (Pisces: Perciformes) and their use to elucidate the stock structure of the host. Parasitology 136: 1209-1219.

Waldman J.R. 1999. The importance of comparative studies in stock analysis. Fish. Res. 43: 237-246.

Scient. ed.: A. Guerra.

Received April 2, 2013. Accepted September 2, 2013.

Published online October 17, 2013. 